\title{
The corporate capture of sustainable development and its transformation into a 'good Anthropocene' historical bloc
}

\section{A captura corporativa do desenvolvimento sustentável e sua transformação em um bloco histórico do "bom antropoceno"}

\section{La captura corporativa del desarrollo sostenible y su transformación en un bloque histórico del "buen antropoceno"}

\begin{abstract}
Inspired by Antonio Gramsci's analysis of bourgeois hegemony and his theoretical formulation of historical blocs, this paper attempts to explain how the concept and practice of sustainable development were captured by corporate interests in the last few decades of the twentieth century and how they were transformed into what we can name a 'good Anthropocene' historical bloc at the beginning of the twentyfirst century. This corporate capture is theorised in terms of the transnational capitalist class as represented by corporate, statist/political, professional and consumerist fractions operating at all levels of an increasingly globalising world. In this essay, I propose the term 'critical Anthropocene narrative', highlighting the dangers posed by the Anthropocene and the need for radical systems' change entailing the end of capitalism and the hierarchical state. The critical Anthropocene narrative, thus, stands in radical opposition to the 'good Anthropocene' narrative which I argue was invented as a strategy to defend the socio-economic status quo by the proponents of sustainable development and their successors in the Anthropocene era, despite the good intentions of many environmentalists working in corporations, governments, NGOs, and international organizations. The paper concludes with some suggestions on how to deal with the potential existential threats to the survival of humanity.
\end{abstract}

Keywords: Sustainable development. The Anthropocene. Historical blocs. Corporate capture. Transnational capitalist class.

Resumo: Inspirado na análise da hegemonia burguesa de Antonio Gramsci e sua formulação teórica de blocos históricos, este artigo tenta explicar como o conceito e a prática do desenvolvimento sustentável foram capturados pelos interesses corporativos

\footnotetext{
${ }^{1}$ London University, London School of Economics (London, Great Britain). author_biographical_data
} 
nas últimas décadas do século 20 e como eles foram transformados em que podemos nomear um bloco histórico "bom antropoceno" no início do século 21. Essa captura corporativa é teorizada em termos da classe capitalista transnacional representada por frações corporativas, estatistas/políticas, profissionais e consumistas que operam em todos os níveis de um mundo cada vez mais globalizado. Neste ensaio proponho o termo "narrativa crítica do Antropoceno", destacando os perigos colocados pelo Antropoceno e a necessidade de mudanças sistêmicas radicais que implicam no fim do capitalismo e do estado hierárquico. A narrativa crítica do Antropoceno, portanto, opõe-se radicalmente à narrativa do "bom Antropoceno" que, segundo argumento, foi inventada como uma estratégia para defender o status quo socioeconômico pelos proponentes do desenvolvimento sustentável e seus sucessores na era do Antropoceno, apesar das boas intenções de muitos ambientalistas que trabalham em corporações, governos, ONGs e organizações internacionais. $\mathrm{O}$ artigo conclui com algumas sugestões sobre como lidar com as possíveis ameaças existenciais à sobrevivência da humanidade.

Palavras-chave: Desenvolvimento sustentável. O Antropoceno. Blocos históricos. Captura corporativa. Classe capitalista transnacional.

Resumen: Inspirado por el análisis de Antonio Gramsci sobre la hegemonía burguesa y su formulación teórica de bloques históricos, este artículo intenta explicar cómo el concepto y la práctica del desarrollo sostenible fueron captados por intereses corporativos en las últimas décadas del siglo $\mathrm{XX}$ y cómo se transformaron en lo que podemos nombrar un bloque histórico del 'buen Antropoceno' a principios del siglo XXI. Esta captura corporativa se teoriza en términos de la clase capitalista transnacional representada por las fracciones corporativas, estatistas/políticas, profesionales y consumistas que operan en todos los niveles de un mundo cada vez más globalizado. En este ensayo, propongo el término "narrativa antropocena crítica", destacando los peligros planteados por el Antropoceno y la necesidad de un cambio radical de sistema que conlleve el fin del capitalismo y el estado jerárquico. La narrativa crítica del Antropoceno, por lo tanto, se opone radicalmente a la narrativa del "buen Antropoceno", que, según sostengo, se inventó como una estrategia para defender el status quo socioeconómico por parte de los defensores del desarrollo sostenible y sus sucesores en la era del Antropoceno, a pesar de buenas intenciones de muchos ambientalistas que trabajan en corporaciones, gobiernos, ONG y organizaciones internacionales. El texto concluye con algunas sugerencias sobre cómo enfrentar las posibles amenazas existenciales para la supervivencia de la humanidad.

Palabras-clave: Desarrollo sostenible. El Antropoceno. Bloques históricos. Captura corporativa. Clase capitalista transnacional.

In the nineteen-nineties, I attempted to highlight the growing connections between the transnational capitalist class (TCC) and global environmental organizations. This research suggested some parallels between the TCC and its culture-ideology of consumerism and emerging transnational environmental elites and their culture-ideology of corporate environmentalism (Sklair, 1994). These parallels can be summed up by the labels 'green consumerism' and 'greenwashing' (compare Willums, 1990 and Greer and Bruno, 1996), ideas 
which fed directly into my work on global system theory and specifically capitalist globalization. The major consequences of this line of thought for the capitalist global system are that the system is fatally compromised by two contradictions - the class polarization crisis and the crisis of ecological unsustainability (Sklair, 2002, p. 48-58 and passim). This paper focuses on the latter crisis.

In my book The Transnational Capitalist Class (2001) I devoted a chapter to an emerging but not much-researched consequence of capitalist globalization, conceptualised as the corporate capture of sustainable development and (following Gramsci) the creation of a sustainable development historical bloc (Sklair, 2001, ch.7). ${ }^{1}$ In my view, the relationships between the global capitalist and the global environmentalist systems can be most fruitfully researched in terms of coalitions that cluster around points along a continuum, rather than two mutually contradictory and irreconcilably opposed sets of social forces or historical blocs. The struggle over the environment began to emerge in the 1960s around the ownership, redefinition and effective monopoly of the public appropriation of what would later be called sustainable development. No doubt, good arguments could be made that ideas like sustainable development are as old as the hills, but my point is that corporate interest in the sustainability of our relations to the planet began seriously in the 1960s, probably provoked by Rachel Carson's groundbreaking Silent Spring, first serialised in the New Yorker and then published as a book in 1962. The misconceived attempts to discredit it by major corporations in the United States backfired spectacularly giving plenty of opportunity for Carson and her supporters to broadcast her message on environmental crisis in the mass media. She is widely credited with providing the impetus for the rapid growth of the environmental movement in the United States and elsewhere. The book was an international best-seller, with British, French, German, Italian, Danish, Swedish, Norwegian, Finnish, Dutch, Spanish, Brazilian, Japanese, Icelandic, Portuguese, Hebrew, and Yugoslav editions. ${ }^{2}$ The success of Silent Spring and the bad publicity it generated for major globalizing corporations in the United States starkly illustrated the urgent need for a more adequate corporate response to environmental issues.

\footnotetext{
${ }^{1}$ For a penetrating analysis of the concept of historical bloc, its relationship with Gramsci's theorisation of hegemony, and its power as a way of activating the more static Marxist versions of base and superstructure, see Boothman (2017).

${ }^{2}$ It is not so well known that Rachael Carson had previously published several equally successful popular science books on marine biology, notably The Sea around Us, translated into even more languages in the 1950s and 1960s. Al Gore (2007) among many others cites her as an inspiration.
} 
The publication of Limits to Growth ( $\mathrm{LtG})$, a report sponsored by the Club of Rome and written by a project team at MIT (Meadows et al., 1972), indicated that establishment opinion was beginning to turn towards a more serious and critical appraisal of the relationship between unlimited growth (the dominant ideology of both capitalist and communist systems) and impending environmental crisis. LtG reputedly sold 30 million copies, has been translated into at least 30 languages, probably the best-selling book ever on the environment. ${ }^{3}$ The Club of Rome is an organization of the great and the good (UN luminaries, former heads of states and other political notables, progressive corporate leaders, philanthropists, scientists of various types, and educators). Citing the traumatic events of 1968 ('The Great Divide'), as the end of the post-war boom gave way to a period of global political unrest, economic uncertainty, and environmental tensions, the Club of Rome took it upon itself to address the 'Predicament of Mankind'. This was accomplished under three general rubrics, namely that the problems were global, that they were long-term, and that they could best be addressed as a 'world problematique' (indicating that limits to growth was the first genuine problem that everyone in the world shared and thus had to be dealt with collectively). Unsurprisingly, the book was welcomed by environmentalists and widely discussed in the print and broadcast media. Though the authors vigorously denied that they were advocating a zero-growth economy, this was the message that many on the right took from the book, and it was roundly condemned and ridiculed by many neoliberal capitalist ideologues. ${ }^{4}$ The Club of Rome has published many follow-up studies and continues to organise many events. ${ }^{5}$

The connections between the leading institutions of global capitalism and global environmentalism grew dramatically in the 1980s and 1990s. In the world of big business, these connections straddled the spectrum from direct and indirect corporate sponsorship of transnational environmental organizations (TEOs) to downright hostility and occasional violence between

\footnotetext{
${ }^{3}$ The term 'sustainable' occurs a few times in the report, 'development' many more times, but there is no mention of 'sustainable development' for which we have to wait until Brundtland in 1987 (see below). 'Climate' merits 6 mentions, 'warming' 1, but neither 'climate change' nor 'global warming' makes an appearance. Given the lack of environmental vocabulary at the time it is even more impressive that LtG had such an impact.

${ }^{4}$ An update of the original report in 1992 had very little impact, being swamped by the umbrella idea of sustainable development. For a history of the book and its many offspring, see: $<$ thesolutionsjournal.com/article/the-history-of-the-limits-to-growth/> All links were accessed and active in July 2018).

${ }^{5}$ In 2017 Roberto Peccei, vice president of the Club of Rome, discussed what steps mankind must take to survive the Anthropocene (www.unisg.it/en/press-office/anthropocene-club-ofrome-conference-pollenzo/). Peccei appears to have been recruited to the 'good' Anthropocene which is where the 'limits to growth' argument, like sustainable development, leads.
} 
the parties and their allies (see Rowell, 1996). A first approximation of TEOs would include those in and around the UN system, notably the United Nations Environment Programme, Commission (subsequently Division) on Sustainable Development, and the Global Environmental Facility; and NGOs that work like corporations, notably the World Conservation Union, WorldWide Fund for Nature (WWF), Environmental Defense Fund, Nature Conservancy, and the World Resources Institute. The major independent and left-leaning environmental NGOs, notably Friends of the Earth and Greenpeace are mainly small-donor funded, nevertheless, they have been known to accept money and work with green business. ${ }^{6}$ To this list must be added the myriad of smaller and usually specific issue-oriented organizations that mushroomed around the Brundtland Report and the UN Conference on Environment and Development in Rio in 1992, and its aftermath (see, for example, Schmidheiny, 1992).

The UN-sponsored Brundtland Report of 1987 can be considered the start of the process of institutionalisation of the sustainable development historical bloc at the global level. ${ }^{7}$ Corporate environmentalism has been the main weapon of those working for the global capitalist system to establish ownership of sustainable development and with it, bring the agents and agencies of global environmentalism over to its ways of thinking and doing. There is abundant evidence to suggest that the four fractions of the transnational capitalist class (corporate, political, professional, consumerist) began to organize what I have conceptualized as the sustainable development historical bloc in the second half of the twentieth century (see Sklair, 2001, chap.7 and chapter notes for sources). The main ideological and practical tasks of the members of this bloc are to deflect attention from the notion of a singular ecological crisis that would call capitalist production and consumption as a whole into serious question. The corporate response was to build up the credibility of the idea that what we face is a series of manageable relatively unrelated environmental challenges. Within this framework, sustainable development can be achieved piecemeal by meeting all these separate challenges as they arise (often referred to as 'end of the pipe solutions'). On the other side of the argument are those within global environmentalism who cling to the idea of an impending singular ecological crisis and argue that it can only be averted by taking action to change the 'system' as a whole (usually but not always conceived as the global capitalist

\footnotetext{
${ }^{6}$ Compare 'The disastrous merger of big business and big green', documenting the gradual move to corporate environmentalism by many green NGOs (Klein, 2014, chap. 6), and Greeno (1998).

${ }^{7}$ Bernstein (2002) provides a meticulous account of the compromise of liberal environmentalism in this period.
} 
system). ${ }^{8}$ The rise of ecological modernization theory, a sociological rationale for the greening of business and industry, implicitly recognised the corporate capture of sustainable development insofar as it saw the environmentally destructive effect of unrestrained capitalism as something that could be managed (even leveraged to bring in more profit) by a more enlightened capitalism (see Hajer, 1995). Given the widely perceived inadequacies of state regulation, the view that the corporations should take more responsibility for managing the environment gained ground. ${ }^{9}$

Not only corporations but also international organizations of various types took it upon themselves to 'do something' about the environment. The European Community introduced a Community-wide environmental auditing scheme in 1993. The World Bank had been discussing the environmental aspects of their lending since the 1970s, with controversial results (see Rich, 1994). ${ }^{10}$ The Environmental Committee of the OECD began to discuss the issue in the early 1980s. In January 1985, shortly after Bhopal, ${ }_{11}^{11}$ the Committee proposed that an environmental management chapter be added to the OECD (voluntary) Guidelines for Multinational Enterprises, first introduced in 1976. The proposal was strongly supported by all the governments of the OECD, with the exception of the UK (the US offered only lukewarm support).

I would not wish to leave the impression that major corporations and smaller businesses all around the world wilfully ignored the evidence piling up that a global environmental crisis was looming or had arrived. In the course of my research for The Transnational capitalist class, I interviewed many corporate environmental executives and some green business groups (see Sklair, 2001, chap.7 and Appendix 1). In most cases, my impression was that these men and women were genuinely concerned about environmental issues but that the corporations they worked for were driven by the bottom lines of profits and short-term stock market pressures. A dialectic of corporate environmentalism seemed to be at work. When all was going well, the

\footnotetext{
${ }^{8}$ I use the rather vague terms 'ecological crisis' and 'environmental crisis' in a purely descriptive sense with no underlying theoretical intention, simply to indicate the problems that sustainable development, corporate environmentalism, and various Anthropocene narratives were designed to combat.

${ }^{9}$ For a wide-ranging analysis of the various dimensions of ecological modernization and case studies of Arco chemical company, Shell, The Body Shop and Ben \& Jerry's, see Robbins (2001).

${ }^{10}$ While this reference is over 20 years old, its central arguments still resonate (Newell, 2012).

${ }^{11}$ For those who need 'Bhopal' explained see Sklair (2001, p. 182-184 and notes 36 and 37 on page 196). Since 1984, there have been many more 'Bhopals' - for regular updates see https:// corporatewatch.org/category/environment/ and its 'Guide to Green Capitalism'.
} 
environment was low priority, but when environmental crises emerged (for example, excessive pollution, toxic waste spills, sweatshop factory fires, resource extraction violations) that could taint the reputation of the company, the environment became high priority and senior executives lined up to beg forgiveness and proclaim green credentials as documented in Holzer (2010), a finely theorized case study of Shell and other major corporations. Twenty years on there have been few fundamental changes apart from, for example, the digital sophistication now available for motor manufacturers to smuggle into their vehicles software that conceals illegal levels of emissions. Researchers who provide scientific support of various kinds to bolster corporate environmentalism and sustainable development are not all malign. Progressive-minded corporate employees or those working on corporatefunded projects in universities and other institutions may genuinely believe that there is no alternative to global capitalism and that the best they can do is try to mitigate the worst effects of the environmental crisis. If you cannot exit the system, at least you can try to improve it. These are people on the fringes of the sustainable development historic bloc, and their expertise can be helpful to those who do work to create alternatives.

How, then, have the debates around the Anthropocene changed the way we understand sustainable development and ecological modernisation? While still working on the TCC, in 2016 I read a book that dramatically changed my research priorities. The book by Ian Angus, Facing the Anthropocene (2015) was one of the first attempts to systematically connect the science of the Anthropocene with the political economy in which it had evolved. Angus is the editor of an online journal Climate \& Capitalism and a leading exponent of ecosocialism, the theory that the only way to save the planet and human life itself is through ecologically sensitive socialist revolution. ${ }^{12}$ This book not only introduced me properly to the term Anthropocene which, like millions of others I had probably read in passing and forgotten about, but also to a body of literature which sent me back to ecological unsustainability and forward to the sociology of Earth System science. This relatively new paradigm puts the various eco-systems of our home planet (climate, oceans, soils, forests, the biosphere which includes humans) into global perspective, notably in terms of positive and negative feedbacks: 'The Anthropocene concerns human impacts on the Earth System, not on the environment' (Hamilton, 2015, p. 2). While the Anthropocene is primarily a geological concept, large social science and

\footnotetext{
${ }^{12}$ For expressions of my admiration for this book, and my disagreement with its conclusions, see my review article (Sklair, 2017).
} 
humanities literature plus many imaginative inputs from creative artists have grown up around it, prompting some to label it the 'Anthropo-scene' (Lorimer, 2015; Sklair, 2019). ${ }^{13}$

The explanation of how the relatively obscure idea of the Anthropocene has captured the imagination of large numbers of natural and social scientists, humanities scholars and creative artists can be found in the efforts of the Anthropocene Working Group (AWG), which was established in 2009 to prepare the scientific community and the general public for the theoretical and practical challenges that lay ahead. While others had used the term 'Anthropocene' or variations of it in the 1980s and even before, the credit for popularising it in the early 2000s usually goes to the Nobel laureate atmospheric chemist Paul Crutzen - having a Nobel prize-winner for a figurehead is clearly a plus for any scientific enterprise. The chairman of the AWG was Jan Zalasiewicz, Professor of Paleobiology at the University of Leicester who, through his publications, media outreach, and promotional skills, has done as much as anyone to disseminate the idea of the Anthropocene in scientific, scholarly, and cultural spheres. ${ }^{14}$ The name Anthropocene is at time of writing still waiting for acceptance into the official nomenclature as a geological epoch by the International Commission on Stratigraphy. This is a long drawn-out process and not all Earth scientists support the application by the AWG that the Holocene epoch should be brought to an end and replaced by the Anthropocene, widely referred to as the Age of Man. ${ }^{15}$ In my view, the central and most important point is not so much that in the Anthropocene humans have become a dominant geologic force, but that this may have catastrophic effects on the Earth system as a whole because the various eco-systems on which human life depends become more and more compromised. The idea that humans have become a dominant force in nature (even if not in geology per se) has a long history. In her muchacclaimed biography of Alexander von Humboldt, Andrea Wulf (2016) explains that in the early 1800s Humboldt developed his idea of humaninduced climate change. 'Nature, Humboldt realized, was a web of life and a global force ... everything was interwoven' as with 'a thousand threads'

\footnotetext{
${ }^{13}$ Good examples of these literatures are Ellis (2018) mainly focused on Earth System science; and edited volumes by Moore (2016) on social sciences; Hamilton et al. (2015) on humanities; Robin and Muir (2015), Jagodzinski (2018) on humanities and creative arts. For my own contributions, see Sklair (2019; 2020, and forthcoming).

${ }^{14}$ I take up the question of how successful the AWG has been in disseminating the idea to publics outside these professional, academic, and cultural bubbles in my research project on the Anthropocene in the mass media (Sklair, forthcoming).

${ }^{15}$ Provoking penetrating feminist critique, notably from Raworth (2014) and Haraway (2016).
} 
(Wulf, 2016, p. 87). ${ }^{16}$ Locher and Fressoz (2012) demonstrate that many French scientists, building on Humboldt's insights, reinforced his ideas. Responses to the risks posed by human impacts varied widely, then as now, within the scientific community as they do for social scientists, humanities scholars, and creative artists today. However, few predicted the extinction of humanity.

In his 2002 paper in Nature Crutzen had argued: 'A daunting task lies ahead for scientists and engineers to guide society towards environmentally sustainable management during the era of the Anthropocene,' including geoengineering projects to 'optimize' climate. This apparently authoritative statement set the scene for what has subsequently been labelled the 'good Anthropocene', in my opinion establishing the world-view that lies behind the creation of the 'good Anthropocene' historical bloc, a direct successor of the corporate capture of sustainable development discussed above.

In this essay I propose the term 'critical Anthropocene narrative', ${ }^{17}$ highlighting the dangers posed by the Anthropocene and the need for radical systems' change entailing the end of capitalism and the hierarchical state (in my view all so-called nation states are bound to be hierarchical). The critical Anthropocene narrative, thus, stands in radical opposition to the 'good Anthropocene' narrative. The widespread use of the slogan 'Welcome to the Anthropocene' (sometimes intended ironically, sometimes not) acts as an enigmatic signifier for the 'good' Anthropocene, sending contradictory messages on complex scientific, personal, and political questions but, I would suggest, its dominant effect is more consistent with 'good' Anthropocene rather than critical Anthropocene narratives. An excellent example of this is the deconstruction of the meanings of a major Anthropocene exhibition in Germany by Jørgensen \& Jørgensen (2016). Along the same lines, the widespread presence of 'Welcome to the Anthropocene' and similarly comforting messages in the mass media and the scholarly literature (even if intended ironically) could be seen as reassurance narratives (Sklair, 2019).

From a critical Anthropocene perspective, sustainable development and the subsequent UN Sustainable Development Goals approach are based on a series of fallacies. The first is that the anthropocentric approach itself (sustainability for people and societies taking precedence over sustainability for the planet) is potentially catastrophic. To put it simply, if our activities

\footnotetext{
${ }^{16}$ Humboldt anticipated themes common to contemporary Anthropocene scholars.

${ }^{17}$ For a wide-ranging analysis of good, bad, and ugly Anthropocenes, see Dalby (2016).
} 
destroy the ecosystems on which human survival depends, we cannot survive. ${ }^{18}$ In much Anthropocene discourse sustainability is being replaced with the slightly more critical idea of resilience, which is not so closely embedded in defending the status quo. However, as Naomi Klein wisely suggests, a more appropriate term might be 'regenerative'. Resilience, she argues, 'is a passive process, implying the ability to absorb blows and get back up. Regeneration, on the other hand, is active: we become full participants in the process of maximizing life's creativity' (Klein, 2014, p. 447). This is a thought that might make profit-driven corporations nervous while at the same time giving inspiration to the rest of us as the Anthropocene grinds inexorably on. However, no-one has as yet resolved the central dilemma of how to help the poorest people in every part of the world out of poverty into a decent standard of living without increasing ecological anthropogenic damage. The focus of much sustainable development literature on the paradox of China where millions 'have been lifted out of poverty' (in the rhetoric of top-down growth) resulting in the emergence of a full-blown culture-ideology of consumerism, brings this dilemma into sharp focus, as Klein frequently notes in her book. ${ }^{19}$

The second fallacy is the idea that 'sustainable consumption' and 'sustainable production' are essentially two sides of the same coin. The real issue I would argue is not 'sustaining' production and consumption but reducing them absolutely which would minimise their destructive effects on all eco-systems and the Earth System as a whole. This raises the contentious issue of degrowth, discussed below. In addition, ecologists wedded to sustainable development argue that 'meeting needs', 'improving quality of life' and 'improving environmental performance' are parts of the solution to the ecological crisis. They are not. They are parts of the problem, particularly in terms of distinguishing real from artificial needs and establishing universal norms for ecologically sound quality of life rather than encouraging the rhetoric of endless growth driven by the culture-ideology of consumerism. No-one benefits in the long-run from the destruction of the planet's capacity to support human life.

Two prominent theorists in the relations between science and politics throw some light on the unenviable choices even the most responsible environmental leaders of major corporations, governments, and journalists

\footnotetext{
${ }^{18}$ For a sober assessment of the science that lies behind this statement, see Ceballos et al. (2017).

${ }^{19}$ See the excellent paper by Marinelli (2018) who skilfully connects sustainable development, the Anthropocene, and ecological civilization/progress in a critical analysis of environmental policies in China.
} 
have to grapple with in the Anthropocene. Stengers (2015) makes the powerful argument that scientists were forced to go public on the potential risks of the Anthropocene before all the scientific results were fully established. Waiting for more definitive evidence could be catastrophic in the long-term when the terrible price of inaction or inadequate action might have to be paid in full. ${ }^{20}$ This uncertainty gave the anthropogenic climate-change deniers many opportunities to keep the debate going around the questions of whether the risks are genuine. Those trying to resolve the new problems of the Anthropocene as well as those still struggling with the contradictions of sustainable development fell, though not very neatly, into two opposing camps, namely merchants of fear (those who acknowledge the dangers of the Anthropocene) or merchants of doubt (usually characterised as climate change deniers). For Latour, Anthropocene politics 'is not a rational debate ... [it is] incredibly easy to make two sides emerge even when there is only one' (Latour, 2015, p. 147). The merchants of fear, various types of radical ecologists, are a small minority, even in the environmental movement though, on occasion, they have been prominent in the mass media. ${ }^{21}$

The claim that there is a fatal contradiction between the growth obsession of global capitalist development and human survival appears to have prima facie plausibility. If this is indeed the case, then the ongoing corporate version of sustainable development and the emerging corporate ideology of the 'good Anthropocene' are both fatally flawed. Clearly, the dominant agents in the global capitalist system had no option but to believe and act as if the contradiction between global capitalism and sustainable development could be resolved by a combination of economic-technological, political, and cultureideology means. Variations on this perspective appear in 'good Anthropocene' manifestos as ecomodernism (the Anthropocene equivalent of ecological modernisation), geoengineering, and radical conservation..$^{22}$ On the other hand, the focus on the human, nonhuman, and posthuman condition in social science and humanities, which dominates much Anthropo-scene scholarship, fascinating as it is intellectually, could also be interpreted as a diversion from the central issue of human and planetary survival in the Anthropocene. ${ }^{23}$ The

\footnotetext{
${ }^{20}$ Vividly portrayed in a dystopian science fiction novel by two distinguished historians of science (Oreskes and Conway, 2014).

${ }^{21}$ The merchants of fear/merchants of doubt frame derives from the work of Naomi Oreskes (see Oreskes and Conway, 2010). Oreskes has been involved with the Anthropocene Working Group.

${ }^{22}$ The Breakthrough Institute. A leading proponent and institutional supporter of strategies to ensure a 'good' Anthropocene (https://thebreakthrough.org/).

${ }^{23} \mathrm{See}$, for example, Hornborg (2017) on the distinction between consequences and agency.
} 
same might also be said of the enormous amount of attention paid by Earth scientists (and, to a lesser degree, social scientists, humanities scholars, and the media) to alternative starting dates for the Anthropocene - scientifically important but nevertheless a distraction.

It is not so easy to decide how to interpret the debate that has arisen between anti-capitalist thinkers who agree that the Anthropocene presents existential risks but cannot accept the name of the concept. They mostly argue that the Anthropocene should be replaced by the Capitalocene. The two most influential proponents of this as the most appropriate name for the current geological epoch are the historian of fossil capitalism, Andreas Malm (2016) and the sociologist Jason Moore whose edited book (Moore, 2016) poses the question 'Anthropocene or Capitalocene?' There is no denying the brilliance and erudition of Malm's account of how fossil fuels created a new era of capitalist production relations, displacing water power and much else besides, but these attributes do not in themselves prove that the Capitalocene is a more appropriate label than the Anthropocene for our present dilemma. To many, the debate might appear to be more a battle for discursive territory between factions of the left than a useful way forward, intellectually or politically. ${ }^{24}$ It is important to remember that the Anthropocene is a geological concept and there are several historical explanations of its consequences. While it is clearly correct to argue that capitalism as a system is most directly responsible for the environmental crisis (polling suggests that most people around the world accept this despite the noise generated by relatively small groups of deniers and sceptics), it is also true that the Anthropocene is inclusive of the human enterprise. We are mostly all complicit via the culture-ideology of consumerism. Rebranding the Anthropocene as the Capitalocene conveniently lets anti-capitalists off the hook to fly around the world critiquing capitalism and making our sometimes ecologically destructive consumer choices. As Donna Haraway argues (in her original though somewhat ambivalent contribution to the Moore collection): 'in so far as the Capitalocene is told in the idiom of fundamentalist Marxism, with all its trappings of Modernity, Progress, and History, that term is subject to the same or fiercer criticism [as the concept of the Anthropocene itself]. The stories of the Anthropocene and the Capitalocene teeter constantly on the brink of becoming much Too Big [sic]' (Haraway, 2016, p. 53-54, see also her note 42, on page 72). And, it must be added, the histories of communist, fascist, social democratic, theocratic, and other

\footnotetext{
${ }^{24}$ For a wide-ranging discussion of Marxism in the Anthropocene, and how the left has dealt with ecological issues more generally see Foster (2016). Cassegård (2017) provides a sharp critique of eco-Marxism from the perspective of Critical Theory.
} 
regimes suggest that most systems are just as bad ecologically. With a few small-scale exceptions, none of them can cope satisfactorily with poverty and the ravages of the growth imperative. However, Haraway's 'Too Big' does suggest that the problem of scale, all the way from small communities to the planetary level, deserves more attention than it currently receives.

I will conclude with a critique of an interesting contribution to debates around the capacity of capitalism to deal with ecological crisis, and some suggestions as to how we could mobilise to deal with the dangers of the Anthropocene. The authors of the theory of 'climate capitalism' argue that proposing a ban on all further coal and oil use is both unrealistic and deeply problematic as it would inhibit economic growth and cause capitalism to collapse. The challenge of climate change means: 'either abandoning capitalism or seeking to find a way for it to grow while gradually replacing coal, oil and gas' (Newell and Paterson, 2010, p. 9). Somewhat reluctantly, they chose the latter option. While this analysis appears reasonable, on further examination its inbuilt contradiction becomes obvious. Newell and Paterson brilliantly deconstruct the problems involved in exiting from a fossil fuel economy while at the same time continuing with business as usual. This is implicit in arguing that you can persuade capitalists and those who currently depend upon them for their livelihoods that, for example, mobilizing market forces to encourage change to renewable sources of energy will somehow resolve the ecological crisis. While there are definite movements in the corporate world in the direction of decarbonisation, the fact that renewables all have their own greenhouse gas emissions (though usually less than those of fossil fuels) is rarely factored in. ${ }^{25}$ Debates flow back and forward: on the one side, those advocating a zero-carbon economy (for example the 'Zero Carbon Britain 2030' programme of the New Economic Foundation, and the transnational Transition Towns movement worldwide), on the other side corporate institutions advocating a low-carbon economy, details unspecified (for example the Business Council for Sustainable Development). However, these are more or less noble aspirations with very little chance of implementation under present circumstances. The contradiction that Newell and Paterson and all those who believe that better, cleaner, more caring capitalism is the answer, cannot escape is that the only way to avoid the risk of potential disaster is to reduce our consumption of everything that uses up natural resources and

\footnotetext{
${ }^{25} \mathrm{~A}$ novel, and possibly more effective, incentive for capitalists and states to exit from fossil fuels, involves persuading insurance companies to refuse cover for new fossil fuel projects (see \#UnfriendCoal campaign). If such campaigns were successful more people might question both capitalism and the obsession with growth.
} 
destroys ecosystems. What is now conceptualised as degrowth (see D'Alisa et al., 2014), as Newell and Paterson imply, would be fatal for capitalism and, I would add, for the hierarchical state and all that goes with it.

Degrowth should be at the centre of all our thinking about sustainable development, ecomodernism, and the Anthropocene, good, bad, or critical. ${ }^{26}$ If we combine the idea of degrowth with Donna Haraway's 'Too Big' (noted above) and place them in the context of Schumacher's classic study, Small is Beautiful (1973) I think we can begin to see one way out of our present dilemma. Schumacher's book challenged many of the orthodoxies of capitalist and socialist economics, notably the obsession with growth. For this, he was called a crank. Schumacher's response to critics was characteristic: 'What's wrong with a crank? It's a small instrument, very simple, it does not involve great capital investment, it is a relatively non-violent technology, and it causes revolutions'.27

Huge transnational corporations and huge corporate states, serviced by huge professional and consumer goods and services organizations increasingly dominate the lives of people everywhere, so it seems obvious that communities organised on a smaller scale might work better and enable people to live happier and more fulfilling lives. This vision of an alternative, radical, progressive, socialist globalization is based on networks of already existing relatively small producer-consumer co-operatives (P-CC) co-operating at a variety of levels to accomplish a variety of communal tasks. To create new communities based on these principles we need to move beyond hierarchy and the state and create forms of non-capitalist, non-exploitative, alternative globalizations in which small-scale P-CCs can network globally, learn from and help each other on a global scale. This will necessitate a double strategy: first to slow down capitalism as will inevitably happen if P-CCs succeed in exiting the capitalist market in one sphere after another, in one place after another; and second to bring into existence a new mode of production based on the different principles and mentalities. Maybe we could call ways of thinking, writing and doing that contribute to these ends, 'socialist anarching'. This would only be possible in small steps, self-generating in a genuinely democratic environment, itself a highly contentious idea. I anticipate that this would begin with the gradual relocation of all food production to the local level, counteracting the enormous ecological damage caused by the food

\footnotetext{
${ }^{26}$ See Burton \& Somerville (2019), an incisive contribution to New Left Review's Debating Green Strategy debates (5) - though they imply the Anthropocene, they don't actually name it.

${ }^{27}$ See http://www.bbc.co.uk/programmes/b079njxm.
} 
industry, notably greenhouse gas emissions due to factory farming and often ridiculous long-distance transportation of ingredients and processed products (food miles). Research on alternative food networks (see Goodman et al., 2012) provides an excellent starting point based on extensive fieldwork, for imagining what might be possible.

Most localisation proposals have been dismissed with the charge that they would represent a retreat into the new middle ages or new tribal communities, and so on. My answer to this is simple. The middle ages did not have the digital technology that P-CCs could call on, notably networking to enable ecologically sensitive and highly efficient localised food production, taking advantage of the possibilities of revolutionizing small-scale manufacturing opened up by alternative technologies such as 3 -D printing. The new warring tribes argument certainly rings true as we look around the world today, but the creation of new mentalities through more empathetic biological and social parenting on which the whole project rests, would help turn the tribes from competitive, violent, and untrustworthy others into cooperating, peaceful, and trustworthy neighbours, near and far. Working patiently to spread the word about the potential dangers and risks of the Anthropocene to all species on our home planet is an essential first step in the creation of genuinely worldwide socialism committed to ecological regeneration and social justice, community by community. ${ }^{28}$ All this might sound like a utopian fantasy, but if my arguments above are proved to be correct, it is no more of a fantasy than sustainable development or the 'good' Anthropocene.

\section{References}

ANGUS, I. Facing the Anthropocene: fossil capitalism and the crisis of the earth system. New York: Monthly Review Press, 2016.

BERNSTEIN, S. The compromise of liberal environmentalism. New York: Columbia University Press, 2002. https://doi.org/10.7312/bern12036

BOOTHMAN, D. Gramsci's historical bloc: structure, hegemony and dialectical interactions. Movimento, Niteroi, v. 4, n. 6, p. 131-150, 2017. https://doi.org/ 10.22409/mov.v0i6.362

BURTON, M.; SOMERVILlE, P. Degrowth: a defence. New Left Review, London, v. 115 , p. $95-104,2019$.

\footnotetext{
${ }^{28}$ For an elaboration of these ideas, see my ongoing project built around the aphorism: 'it is easier to imagine the end of the world than the end of capitalism' (Sklair, 2016).
} 
CASSEGÅRD, C. Eco-Marxism and the critical theory of nature: two perspectives on ecology and dialectics. Distinktion: Journal of Social Theory, [S. l.], v. 18, n. 3, p. 314-332, 2017. https://doi.org/10.1080/1600910x.2017.1324502

CEBALLOS, G.; EHRLICH, P.; DIRZO, R. Biological annihilation via the ongoing sixth mass extinction signaled by vertebrate population losses and declines. Proceedings of the National Academy of Sciences (USA), 2017. https://doi.org/ 10.1073/pnas. 1704949114

CRUTZEN, P. Geology of mankind. Nature, v. 415, n. 6867, p. 23, 2002. https://doi. org/10.1038/415023a.

DALBY, S. Framing the Anthropocene: the good, the bad and the ugly. The Anthropocene Review, [S. l.], v. 2, n. 2, p. 102-106, 2016. https://doi.org/ $10.1177 / 2053019615618681$

D'ALISA, G.; DEMARIA, F.; KALLIS, G. (ed.) Degrowth: a vocabulary for a new era. London: Routledge, 2014. https://doi.org/10.4324/9780203796146

ELLIS, E. Anthropocene: a very short introduction. Oxford: Oxford University Press, 2018. https://doi.org/10.1093/actrade/9780198792987.001.0001

FOSTER, J. B. Marxism in the Anthropocene: dialectical rifts on the left. International Critical Thought. v. 6, n. 3, p. 393-421, 2016. https://doi.org/10.1080/21598282.201 6.1197787

GOODMAN, D.; DUPOIS, M.; GOODMAN, M. Alternative food networks: knowledge, practice, and politics. New York: Routledge, 2012. https://doi.org/ $10.4324 / 9780203804520$

GORE, A. Rachel Carson and Silent Spring. In: Peter Matthiessen (ed.). Courage for the Earth. New York: Houghton, 2007. p. 63-78.

GREENO, J. (ed.). Making business sense of sustainable development. Cambridge, MA: Arthur D. Little, 1998.

GREER, J.; BRUNO, K. Greenwash: the reality behind corporate environmentalism. Penang: Third World Network, 1996.

HAJER, M. The politics of environmental discourse: ecological modernization and the policy process. Oxford: Oxford University Press, 1995.

HAMILTON, C. Getting the Anthropocene so wrong. The Anthropocene Review. [S. l.], v. 3, n. 1, p. 33-51, 2015. https://doi.org/10.1177/2053019615618681

HAMILTON, C.; BONNEUIL, C.; Gemenne, F. (eds.) The Anthropocene and global environmental crisis: rethinking modernity in a new epoch. London: Routledge, 2015. https://doi.org/10.4324/9781315743424-1 
HARAWAY, D. Staying with the trouble: Anthropocene, Capitalocene, Chthulucene. In: MOORE, J. (ed.). Anthropocene or Capitalocene? Nature, history and the crisis of capitalism. Oakland CA: PM Press, 2016. p. 34-76. https://doi.org/ 10.1215/9780822373780-005

HOLZER, B. Moralizing the corporation: transnational activism and corporate accountability. Cheltenham: Edward Elgar, 2010. https://doi.org/10.4337/978184 9806817

HORNBORG, A. Artifacts have consequences, not agency: toward a critical theory of global environmental history. European Journal of Social Theory, London, v. 20, n. 1, p. 95-110, 2017. https://doi.org/10.1177/1368431016640536

JAGODZINSKI, J. (ed.) Interrogating the Anthropocene: ecology, aesthetics, pedagogy, and the future in question. London: Palgrave Macmillan, 2018. https://doi. org/10.1007/978-3-319-78747-3

JØRGENSEN, F.; JØRGENSEN, D. The Anthropocene as a history of technology: "Welcome to the Anthropocene". Technology and Culture, Chicago, v. 57, n. 1, p. 231-237, 2016. https://doi.org/10.1353/tech.2016.0026

KLEIN, N. This changes everything: capitalism vs the climate. London: Penguin, 2014.

LATOUR, B. Telling friends from foes in the time of the Anthropocene. In: HAMILTON, C.; BONNEUIL, C.; GEMENNE, F. (ed.). The Anthropocene and global environmental crisis: rethinking modernity in a new epoch. London: Routledge, 2015. p. 145-155. https://doi.org/10.4324/9781315743424-12

LOCHER, F.; FRESSOZ, J.-B. Modernity's frail climate: a climate history of environmental reflexivity. Critical Inquiry, Chicago, v. 38, n. 3, p. 579-598, 2012. https://doi.org/10.1086/664552

LORIMER, J. The Anthropo-scene: a guide for the perplexed. Social Studies of Science, London, v. 47, n. 1, p. 117-142, 2017. https://doi.org/10.1177/03063127166 71039

MALM, A. Fossil capitalism: the rise of steam power and the roots of global warming. London: Verso, 2016.

MARINELLI, M. How to build a "beautiful China" in the Anthropocene: the political discourse and the intellectual debate on ecological civilization. Journal of Chinese Political Science, [S. l.], v. 23, n. 3, p. 365-386, 2018. https://doi.org/ 10.1007/s11366-018-9538-7

MEADOWS, D. H.; MEADOWS, D. L.; RANDERS, J.; BEHRENS, W. The limits to growth. New York: New American Library, 1972.

MOORE, J. (ed.). Anthropocene or Capitalocene? Nature, history and the crisis of capitalism. Oakland CA: PM Press, 2016. 
NEWELL, P. Globalization and the environment: capitalism, ecology and power. Cambridge: Polity, 2012.

NEWELL, P.; PATERSON, M. Climate capitalism: global warming and the transformation of the global economy. Cambridge: Cambridge University Press, 2010. https://doi.org/10.1017/cbo9780511761850

ORESKES, N.; CONWAY, E. Merchants of doubt: how a handful of scientists obscured the truth on issues from tobacco smoke to global warming. London: Bloomsbury, 2010. https://doi.org/10.1007/s11016-011-9639-9

ORESKES, N.; CONWAY, E. The collapse of Western civilization. A view from the future. New York: Columbia University Press, 2014. https://doi.org/10.7312/ columbia/9780231169547.001.0001

RAWORTH, K. Must the Anthropocene be a Manthropocene? The Guardian, 2014. Available: theguardian.com/commentisfree/2014/oct/20/anthropocene-workinggroup-science-gender-bias.

RICH, B. Mortgaging the Earth: The World Bank, environmental improvement and the crisis of development. London: Earthscan, 1994.

ROBIN, L.; MUIR, C. Slamming the Anthropocene: performing climate change in museums (reCollections). 2015. Available: https://umaincertaantropologia.org/ 2015/05/02/slamming-the-anthropocene-performing-climate-change-in-museumsrecollections/.

ROBBINS, P. T. Greening the corporation: management strategy and the environmental challenge. London: Earthscan, 2001.

ROWELL, A. Green backlash: global subversion of the environmental movement. London: Routledge, 1996.

SCHMIDHEINY, S. Changing course: a global business perspective on development and the environment. Cambridge MA: MIT Press, 1992.

SCHUMACHER, E. F. Small is beautiful: a study of economics as if people mattered. London: Blond and Briggs, 1973.

SEMEL, L. Anthropocene, catastrophism and green political theory. In: HAMILTON, C.; BONNEUIL, C.; GEMENNE, F. (ed.). The Anthropocene and global environmental crisis: rethinking modernity in a new epoch. London: Routledge, 2015. p. 88-99. https://doi.org/10.4324/9781315743424-1

SKLAIR, Leslie. Capitalism and development in global perspective. In: SKLAIR, Leslie (ed.). Capitalism and development. London: Routledge, 1994. https://doi. org/10.1177/000169939704000206 
SKLAIR, Leslie. The transnational capitalist class. Oxford: Blackwell, 2001.

SKLAIR, Leslie. Globalization: capitalism and its alternatives. Oxford: Oxford University Press, 2002.

SKLAIR, Leslie. Half-baked. Philosophica Critica, v. 2, n. 2, p. 103-116, 2016.

SKLAIR, Leslie. Review article: sleepwalking through the Anthropocene. British Journal of Sociology, London, v. 68, n. 4, p. 775-784, 2017. https://doi.org/10.1111/ $1468-4446.12304$

SKLAIR, Leslie. The Anthropocene media project: mass media on human impacts on the earth system. Visions of Sustainability, n. 10, 2018. Available: ojs.unito.it/index. $\mathrm{php} /$ visions/article/view/2740/2519.

SKLAIR, Leslie. Globalization and the challenge of the Anthropocene. In: ROSSI, I. (ed.). New frontiers in globalisation research. New York: Springer (forthcoming), 2019.

SKLAIR, Leslie. The Anthropocene in global media: neutralizing the risk. London: Routledge. (forthcoming).

SKLAIR, L. Terraforming: the Anthropo-scene confronts architecture. In: JONES, P. (ed.). Sociology and Architecture. London: Routledge (forthcoming - 2020).

STENGERS, I. Accepting the reality of Gaia: a fundamental shift. In: HAMILTON, C.; BONNEUIL, C.; GEMENNE, F. (ed.). The Anthropocene and global environmental crisis: rethinking modernity in a new epoch. London: Routledge, 2015. p. 134-44. https://doi.org/10.4324/9781315743424-11

WILLUMS, J. (ed.). The greening of enterprise: business leaders speak out. Bergen: International Chamber of Commerce, 1990.

WULF, A. The invention of nature: the adventures of Alexander von Humboldt, the lost hero of science. London: John Murray, 2016.

Received at: 29 Sept. 2018

Approved at: 15 Jan. 2019

Published at: 30 July 2019

Corresponding author:

Leslie Sklair

London School of Economics

London WC2A 2AE, United Kingdom

LESLIE SKLAIR $<$ L.Sklair@1se.ac.uk>

Emeritus professor of Sociology at the London School of Economics and Political Science; Associate Fellow of the Institute for the Study of the Americas at the University of London (London, Great Britain).

Orcid: https://orcid.org/0000-0002-9582-9684 